\title{
Strategy In Support Of Micro, Small And Medium Agro-Based
}

\author{
Fitra Ariansyah $^{1}$, Laode Asrul $^{2}$, Eymal, B. Demmallino ${ }^{3}$ \\ ${ }^{1}$ Program Studi Agribisnis, Sekolah Pascasarjana, Universitas Hasanuddin \\ Makassar, Indonesia \\ 2,3 Departemen Sosial Ekonomi Pertanian, Universitas Hasanuddin, Makassar, Indonesia \\ ${ }^{*}$ Corresponding author: \\ Email: fitraariansyah@gmail.com
}

\begin{abstract}
.
This study aims to identify and evaluate the factors including internal (strengths and weaknesses) and external scope (opportunities and threats) in determining the strategy of the Balai Diklat in support the growth of agro-based micro, small and medium enterprises in Makassar City, as well as to determine the Balai Diklat strategy with a deep SWOT analysis support the growth of small and medium agrobased enterprises in the City Area Makassar. Data collection techniques use observation, documentation, interview, with the analysis used is the SWOT analysis. Research result indicates that the factors comprising the internal environment with pay attention to the strengths and weaknesses and the external environment, namely opportunities and threats. Wherefrom the analysis of the internal and external environment hence the results of this study the Makassar Industrial Education and Training Center still has strength and great opportunities in overcoming weaknesses and threats. From the analysis of the results of strategy determination using SWOT analysis, including strategic planning, strategy determination, and decision-making stages regarding the strategy, the strategy carried out by BDI Makassar in encouraging the growth of agro-based micro, small and medium enterprises

Develop competency-based training modules and curriculum, Implement monitoring and evaluating programs/activities, recruiting processing machine instructors, general graphic and functional design instructor, Organizing 3 in 1 training, competency-based industrial system training and business incubator, and Improve the quality of human resources by attending training, industrial apprenticeships and writing $K T I$.
\end{abstract}

Keywords: MSME strategy, development

\section{INTRODUCTION}

Human Resources Development is one of the priorities in future industrial development in Indonesia, Law. 3 of 2014 explained that the existence of the functions and roles of education and training (Diklat) providers in order to have an impact in the development of human resources its orientation is one of the priorities in industrial development in the future, a human resource strategy is needed. One of the steps taken by the Ministry of Industry, in this case, is the Pusdiklat Industry is by repositioning the entire work unit of the education unit and Industrial Training (BDI) Makassar. Functions and roles of the Industrial Training Center in Makassar which has the task of increasing the competence of human resources and apparatus the business world in the industrial sector. Where in carrying out its activities as Pusdiklat for agro-based micro, small and medium enterprises organize 3 (three) training, namely training related to the 
development of IKM, training related to development priority industries, and training cooperation. However, there are findings in the field that there is still a mismatch of requirements for training participants that have been applied by the Makassar Industrial Training Center. These requirements include education Finally, at least junior high school equivalent, not having the status of PNS / TNI / POLRI, bring a letter duties of the Business Group / Association / Cooperative, Minimum Age 17 years and Maximum 45 years, has never attended the same type of training before at the Balai Makassar Industrial Education and Training, have an able-bodied letter. Apart from that utilization of knowledge and Skills obtained to start running/improving micro, small and medium enterprises activities has not been carried out optimally so that participants often fail the competency test.

Judging from the problems faced by the Industrial Training Center in Makassar, it seems that it has not been able to increase the number of agro-based micros, small and medium enterprises. The second problem is that the temporary data in the field shows that agro-based small and medium enterprises and training participants in 2019 in Makassar have decreased. So that with a decrease in the number of training participants in 2019, the training strategy for the Industrial Training Center has not been said to be effective. The ineffective implementation of education and training by the Industrial Education and Training Center in Makassar is the lack of availability of machinery and equipment infrastructure and in addition to the reduced number of human resources in the last 5 years. With the ineffectiveness of the implementation of the training, it is necessary to establish an education and training strategy in order to support the growth of agro MSMEs. Where in the education and training strategy research, a SWOT analysis is used. Kurniawan, Dhaka Amalia [1] conducted community service to help MSMEs to be able to formulate and optimize their business development strategies so that it needs to be analyzed with a SWOT approach. Alumni, Raden, et.al. [2] The results of his research prove that training and coaching, either individually or collectively, have a significant influence on the development of small businesses. Amalia, A. Andrei Nur's [3] research results show that the development strategy is formulated using SWOT analysis and prioritized using AHP. Wicaksono, Arie [4], Strengthening human resources (HR) needs to be done so that companies can add and train human resources, especially professional technicians.

According to Afifuddin [5], MSME development can be interpreted as an effort to improve the conceptual, theoretical, technical, and moral abilities of individuals in accordance with the needs of a job or position through education and training. According to Kuncoro [6], the empowerment strategies that have been pursued so far can be classified into several aspects, including increasing productivity/turnover/utilization rate/occupancy rate, increasing marketing capabilities, developing human resources. UMKM are productive business units that stand-alone, which are carried out by individuals or business entities in all sectors of the economy. In principle, the distinction between Micro Enterprises (UMI), Small Enterprises (UK), 
Medium Enterprises (UM), and Large Enterprises (UB) is generally based on the initial asset value (excluding land and buildings), average turnover per year, or the number of permanent workers [7]. The current government policy also helps access capital for the sustainability of MSMEs, because the capital difficulties faced by MSMEs currently still exist, because MSMEs have not been touched by financial institutions [8]. One of the roles of MSMEs is to provide broad economic services to the community, the process of equalization and increase in community income, promote economic growth, and create national stability [10]. According to Maskun [11], community capacity development is a development approach based on real strengths from below.

According to Sedarmayanti [12], Strategy is a unified, broad, and integrated plan that links the advantages of corporate strategy with environmental challenges, designed to ensure that the main goals of the company can be achieved through proper implementation by the organization. According to Tjiptono [13], the strategy is a coherent and integrative decision pattern, which determines and confirms organizational intentions in terms of long-term goals. Kotler and Armstrong [14] define strategy as a declaration of intent that defines the means to achieve goals and takes into account the allocation of company resources that are important for the long term and matching resources and capabilities to the external environment. According to Porter [15] strategies that can help organizations gain competitive advantage, namely cost advantages, differentiation, and focus.

According to Fahmi [16], strategic management is a plan that is prepared and managed by taking into account various sides with the aim that the influence of the plan can have a positive impact on the organization in the long term. In other words, the management strategy is intended to make the organization a unit capable of displaying high performance because a successful organization is an organization whose level of effectiveness and productivity is getting higher and higher, Siagian [17]. According to Pearce and Robinson in Solihin [18] that strategic management is a series of managerial decisions and actions resulting from the process of formulating and implementing plans with the aim of achieving competitive advantage. Udaya, et al. [19] said that all activities to achieve long-term goals, namely achieving the company's vision and mission, are called strategic management. Robbins and Coulter [20] strategic management are what managers do to develop organizational strategy. This is an important task that involves all of the basic management functions - planning, organizing, leading, and controlling. One of the benefits of strategic management according to David [21] is to help organizations make better strategies by using a more systematic, logical, rational approach to the choice of strategy.

The importance of developing resources through training in order to improve the quality of the organization's human resources. Training according to Rivai [22] is a process of systematically changing employee behavior to achieve organizational goals. According to Lubis [23], the definition of training is an attempt to overcome any gaps 
between the company's needs and the abilities possessed by employees. Meanwhile, according to Sudaryono, et al. [24] said that training is a short-term education that usually focuses more on useful practices to improve employee performance and to reduce errors in work. Community empowerment according to Mardikanto [24] is an effort to provide power (empowerment) or strengthening (strengthening) to the community. Community development according to Zubaedi [25] is an effort to develop a community condition in a sustainable and active manner based on the principles of social justice and mutual respect.

According to Rangkuti [26], SWOT analysis is a systematic identification of various factors to formulate a company strategy. SWOT analysis has good and profound implications for successful designs and strategies, Sedarmayanti [27]. The result of the SWOT analysis is the identification of the company's distinctive competencies derived from the company's internal resources and capabilities as well as a number of opportunities that have not been exploited by the company, for example, due to the company's internal weaknesses and capabilities.

Based on the background of the problems above, the purpose of this study is to analyze the factors included in the internal and external environment that determine the strategy of the Industrial Training Center in supporting the growth of agro-based micro, small and medium enterprises in the Makassar city area, how to determine the strategy of the Industrial Training Center in supporting the growth of agro-based micro, small and medium enterprises in Makassar City using a SWOT analysis.

\section{METHODS}

This study used the descriptive qualitative method. (Moleong, 2008: 6) explains that descriptive research is research that describes and describes the current state of the research object as it is based on facts. This research is an attempt to reveal problems or circumstances or events as they are so that they only act as fact revealers. The research results are emphasized to provide an objective picture of the actual condition of the object under study. Questions with the question word "why", "what reason" and "how" will always be used by researchers. The primary data in this study were taken from the results of observation activities, documentation activities, and interviewees.

Secondary data in research are those obtained indirectly through intermediary media (results from other parties) or used by other institutions that are not processors but can be used in a study. Secondary data in this study is in the form of notes or documentary data reports by other institutions that are published and related to this research, both from other units within one ministry of industry agency or from other agencies related to the Makassar Industrial Training Center Data collection techniques through observation, documentation, and interviews. The SWOT data analysis technique used can be seen in the image below; 


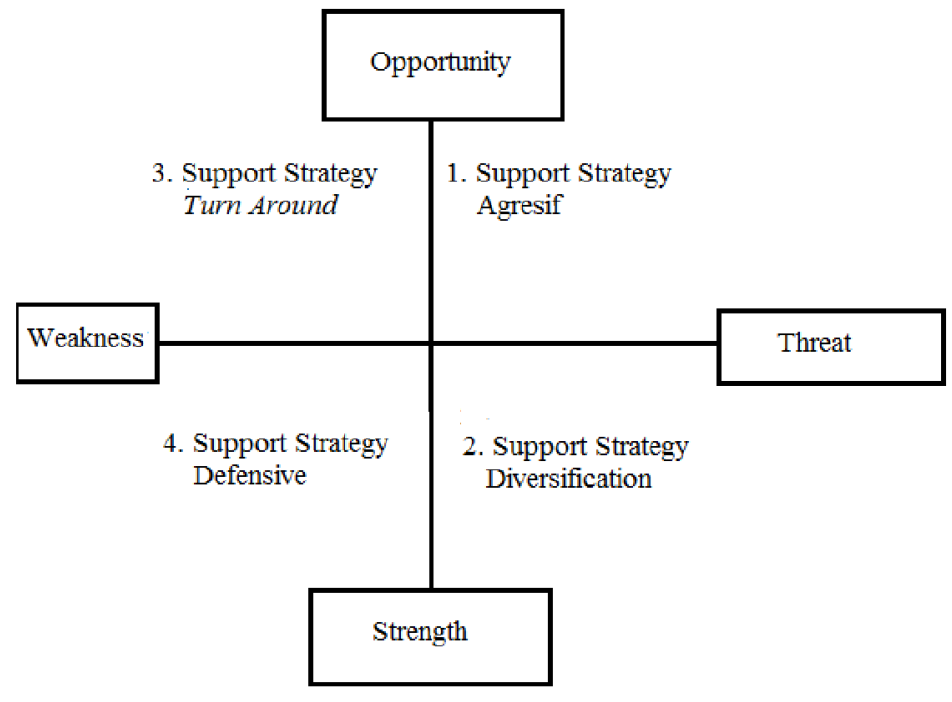

Fig.1 Analysis Model SWOT

\section{RESULT AND DISCUSSION}

\section{Internal Strategy Factor Matrix}

After filling out the questionnaire by the respondents, namely BDI Makassar employees such as the Widyaswara functional, the Head of Development and Cooperation of the Education and Training Center, the functional training instructor, the Head of the Education and Training Center, the head of BDI, and the Head of Sub. Administration. Based on the results of respondents' answers regarding the assessment of IFAS conditions (Attachment 2) and regarding the urgency of handling IFAS (Attachment 3), the IFAS matrix can be presented, namely:

Tabel 1. Internal Strategy Factor Matrix at the Makassar Industrial Training Center

\begin{tabular}{|c|l|c|c|c|}
\hline No & \multicolumn{1}{|c|}{ Internal Strategy Factor Matrix } & Weight & Rating & $\begin{array}{c}\text { Weight } \\
\text { Rating }\end{array}$ \\
\hline A. Strengths & & 0,210 & 3,31 & 0,695 \\
\hline 1 & $\begin{array}{l}\text { Playing the facilities and infrastructure } \\
\text { adequate (teaching factories, machines and } \\
\text { Equipment) }\end{array}$ & 0,265 & 3,31 & 0,875 \\
\hline 2 & $\begin{array}{l}\text { SKKN for seaweed processing, processing } \\
\text { cocoa, the hotel and tourism sub-sector } \\
\text { restaurant and food industry }\end{array}$ & 0,257 & 3,31 & 0,849 \\
\hline 3 & $\begin{array}{l}\text { Experience in organizing education and training } \\
\text { Disputed LSP and TUK }\end{array}$ & & & \\
\hline B. Weaknesses & & & \\
\hline
\end{tabular}

http://ijstm.inarah.co.id 


\begin{tabular}{|c|l|c|c|c|}
\hline 1 & Unavailability of machine instructors and & 0,136 & 3,31 & 0,450 \\
\cline { 3 - 5 } & equipment and graphic design instructors & & & \\
\hline 2 & $\begin{array}{l}\text { Reduced number of human resources in 5 years } \\
\text { ahead of retirement }\end{array}$ & 0,132 & 3,31 & 0,438 \\
\cline { 2 - 5 } & & & \\
\hline \multicolumn{2}{|c|}{ Total Weight X Rating } & 1,00 & & 3,31 \\
\hline
\end{tabular}

Based on table 5.1, the internal strategy factor matrix (IFAS) at BDI Makassar where the IFAS score is 3.31. It can be said that the Makassar Industrial Training Center has strong internal strength. The strength factor that has a big role is the SKKN for seaweed processing, cocoa processing, the tourism sector, the hotel, restaurant, and food industry sub-sector, followed by experience in implementing licensed LSP and TUK divisions.Then in the IFAS matrix, it can be seen that the biggest weakness score in this study is the unavailability of processing machine instructors and graphic design instructors. So this is what BDI needs to pay attention to in improving processing machine instructors and graphic design instructors.

\section{Matriks faktor Strategi Eksternal (EFAS)}

Based on the results of distributing questionnaires to 13 respondents who are employees of the Makassar Industrial Education and Training Center, the determination of weight and rating (attachment 4 and attachment 5) can then be presented with an external strategy matrix (EFAS) which can be seen in Table 5.2 below:

Table.2 Matrix of External Strategy Factors (EFAS) at the Makassar Industrial Training Center

\begin{tabular}{|c|l|c|c|c|}
\hline No & \multicolumn{1}{|c|}{ Eksternal Strategy Factor Matrix } & Weight & Rating & $\begin{array}{c}\text { Weight } \\
\text { Rating }\end{array}$ \\
\hline A. Opportunitie & & & \\
\hline 1 & Wide working area coverage & 0,192 & 2,85 & 0,546 \\
\hline 2 & MEA (ASEAN Economic Community) & 0,166 & 2,62 & 0,433 \\
\hline \multirow{2}{*}{3} & $\begin{array}{l}\text { The existence of other agro potential uses } \\
\text { machines/equipment available at BDI } \\
\text { Makassar }\end{array}$ & 0,169 & 3,00 & 0,506 \\
\cline { 2 - 5 } & & & & \\
\hline \multirow{2}{*}{4} & $\begin{array}{l}\text { Collaboration with Ditjend IKM and Ditjend } \\
\text { Agro }\end{array}$ & 0,151 & 2,85 & 0,430 \\
\hline \multirow{2}{*}{ B. Threats } & & & \\
\hline 1 & $\begin{array}{l}\text { Limited access to industrial companies } \\
\text { seaweed }\end{array}$ & 0,064 & 3,15 & 0,202 \\
\hline 2 & Limited cocoa industry companies & 0,070 & 3,08 & 0,215 \\
\hline \multirow{2}{*}{3} & $\begin{array}{l}\text { The limited scope of specialization } \\
\text { BDI Makassar (Seaweed, Cocoa and } \\
\text { Packaging) }\end{array}$ & 0,099 & 2,85 & 0,281 \\
\cline { 2 - 5 } & & & \\
\hline
\end{tabular}




\begin{tabular}{|c|c|c|c|c|}
\hline \multirow[t]{2}{*}{4} & \multirow{2}{*}{$\begin{array}{l}\text { Lack of cooperation with } \\
\text { seaweed and cocoa associations }\end{array}$} & 0,090 & 3,23 & 0,291 \\
\hline & & & & \\
\hline & Total Weight X Rating & 1,00 & & 2,90 \\
\hline
\end{tabular}

Based on the external strategy factor matrix (EFAS) at the Makassar Industrial Training Center with a large score in the EFAS matrix of 2.90. It can be said that the EFAS score is categorized as sufficient. Where the score of the respondent's answer for the biggest opportunity factor is from the results of the distribution of the Asean Economic Community (MEA) questionnaire and added by other agro potentials that still use machines/equipment available at BDI Makassar. Then the biggest weakness factor in this study is the lack of cooperation with seaweed and cocoa associations, so this needs to be overcome by increasing the scope of specialization of BDI Makassar so that from the evaluation results in the IFAS and EFAS matrix in the SWOT analysis, the results will be presented. determining the total weight score of each of the strengths, weaknesses, opportunities, and threats which can be described as follows:

a. Strength score; The magnitude of the strength score in the IFAS matrix results is $2.42(0.695+0.875+0.849)$

b. Weakness score; The magnitude of the weakness score in the IFAS matrix is 0.89 $(0.450+9.438)$

c. Odds score; The magnitude of the probability score in the IFAS matrix is 1.92 $(0.546+0.433+0.506+0.430)$

d. Threat score; The amount of the threat score in the IFAS matrix is $0.93(0.202+$ $0.215+0.281+0.291)$

So that to calculate the coordinates of the internal analysis and external analysis, namely:

a. Internal coordinate analysis (total strength score - total weakness score) $=2.42$ $0.89=1.53$

b. External analysis coordinate/total chance score - total threat score) $=1.92-0.99=$ 0.93

Based on the identification results of internal strategic factors and external strategic factors, it can be described in a Cartesian diagram, namely:

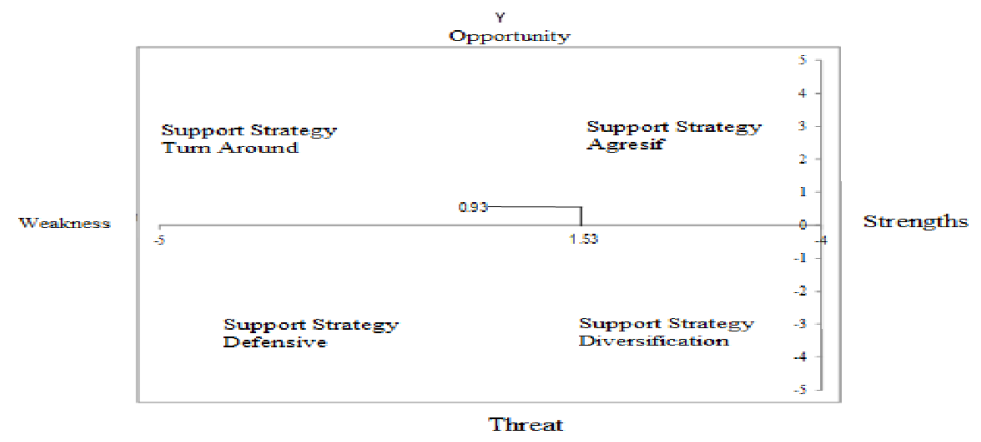

Fig 2. Cartesian Diagram of SWOT Analysis

http://ijstm.inarah.co.id 
Before conducting a SWOT analysis by considering external and internal factors through the use of the strength factor, the opportunities there are, the strategy formulation stage can be carried out. Where in the formulation of the strategy, namely determining the appropriate stage of the matching process in the Makassar Industrial Education and Training Center, because in determining the strategy, management tools are used, namely the internal-external matrix (IE) and the SWOT matrix.

\section{Matriks Internal-Eksternal (IE)}

The internal-external matrix (IE) is useful for positioning a strategy into a matrix consisting of two dimensions, namely: the total score and IFAS matrix on the X-axis with the total EFAS score on the Y-axis. So that the IFAS matrix obtained a total score of 3.31 and in EFAS matrix obtained a total score of 2.90. This can be presented in an internal-external (IE) matrix as follows:

\section{Internal-External Analysis Matrix}

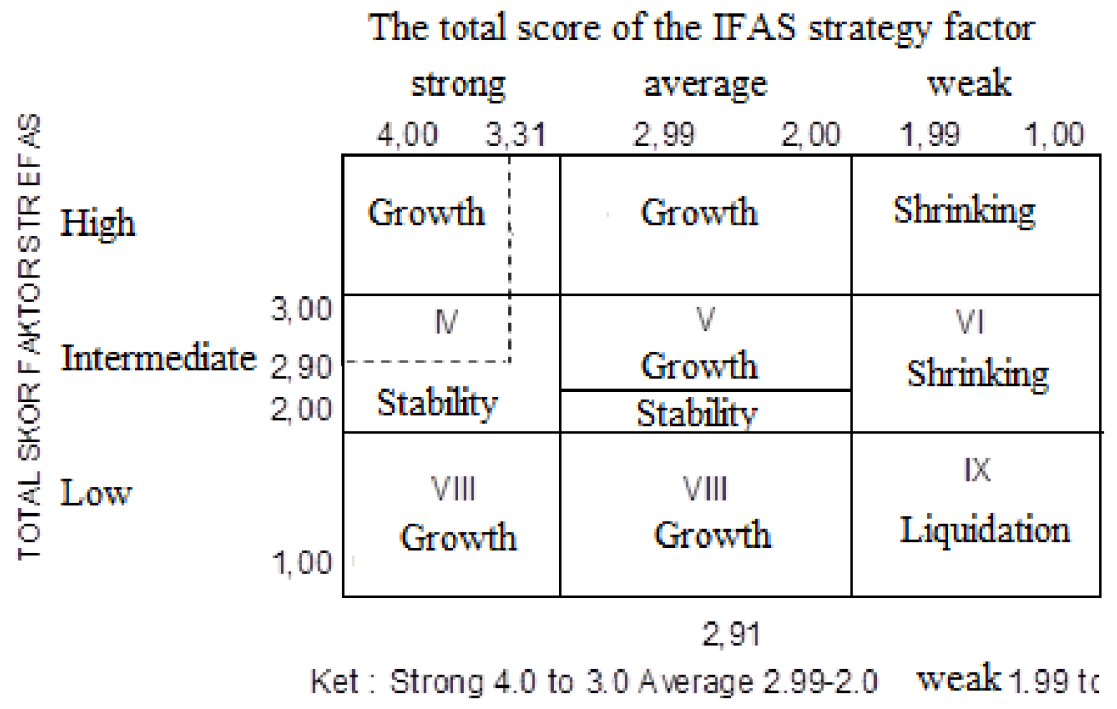

Fig3. Internal-External Matrix (IE) in Strategy Determination at the Makassar Industrial Training Center

Figure 5.3 is the internal-external matrix in the SWOT analysis which shows that the strategy formulation stage used by the Makassar Industrial Education and Training Agency means that the strategy that can be used by the Industrial Training Center is a growth strategy. In this strategy, it shows that in increasing training activities in the case of the agro-industry for a number of MSMEs, BDI Makassar takes advantage of the strengths and opportunities it has in overcoming the weaknesses and threats it has, so a strategy can be formulated to achieve goals through the following SWOT matrix 
Table 3. SWOT Matrix in Strategy Determination at the Makassar Industrial Training Center

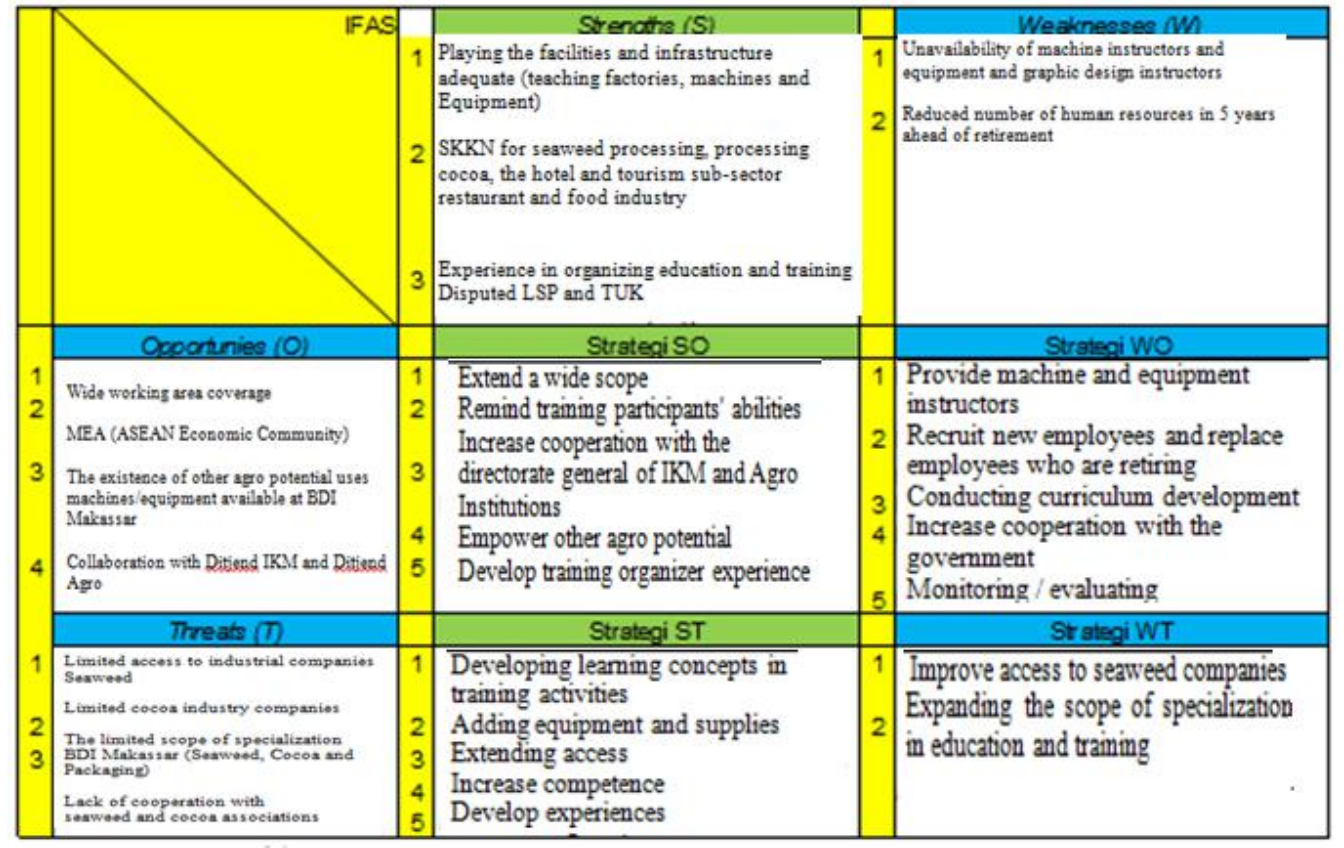

Based on the SWOT matrix that has been stated in decision making in determining the chosen strategy in the implementation of the agro-industry training, especially at the Industrial Training Center in determining the strategy, namely:

1. Extend a wide scope

2. Remind training participants' abilities

3. Increase cooperation with the directorate general of IKM and Agro Institutions

4. Empower other agro potential

5. Develop training organizer experience

6. Provide machine and equipment instructors

7. Recruit new employees and replace employees who are retiring

8. Conducting curriculum development

9. Increase cooperation with the government

10. Monitoring / evaluating

11. Developing learning concepts in training activities

12. Adding equipment and supplies

13. Extending access

14. Increase competence

15. Develop experiences

16. Improve access to seaweed companies

17. Expanding the scope of specialization in education and training 


\section{CONCLUSION}

The results of this analysis and research through direct observation at BDI Makassar, the factors consisting of the internal environment by taking into account the strengths and weaknesses and the external environment, namely opportunities and threats. Wherefrom the results of the analysis of the internal and external environment, the results of this study of the Makassar Industrial Training Center still have great strengths and opportunities in overcoming weaknesses and threats. From the results of the analysis of strategy determination using SWOT analysis, including strategic planning, strategy determination and decision-making stages regarding strategies, the strategies carried out by BDI Makassar in encouraging the growth of agro-based micro, small and medium enterprises are: Developing competency-based training modules and curriculum, Implementing monitoring and evaluating programs/activities, recruiting processing machine instructors, graphic design and general functional instructors, organizing 3 in 1 training, competency-based industrial system training and business incubators, improving human resource quality by attending training, industrial apprenticeships and writing KTI, Carrying out development activities facilities and infrastructure as well as establishing cooperation or promotion with the industrial world/association

\section{ACKNOWLEDGMENTS}

The authors are grateful to Hasanuddin University, to the Agribusiness Study Program at Postgraduate, and to the Department of Agricultural Socio-Economics. Thank to Program Studi Agribisnis, Sekolah Pascasarjana, Universitas Hasanuddin, Makassar, Indonesia and thank to Departemen Sosial Ekonomi Pertanian, Universitas Hasanuddin, Makassar, Indonesia. We also thank Team author for your good cooperation.

\section{REFERENCES}

[1] Kurniawan, Dhika Amalia (2020), Pelatihan Analisis Swot dan BMC pada Asosiasi UMKM Ponorogo. Jurnal Cendekia (Jurnal Pengabdian Masyarakat), Vol. 2, No. 1. ISSN : 2685-130X.

[2] Alhempi, Raden dan Wismar Harianto, (2013), Pengaruh Pelatihan dan Pembinaan terhadap Pengembangan Usaha Kecil pada Program Kemitraan Bina Lingkungan di Telkom Pekanbaru, Media Riset Bisnis \& Manajemen, Vol. 13, No. 1, April 2013pp. 20-38.

[3] Amalia, A. Andiri Nur (2017), Strategi pengembangan IKM Pengeringan Ikan di Kabupaten Wajo Sulawesi Selatan, Jurnal Sains \& Teknologi, Vol. 17, No. 1:80-85, ISSN 1411-4674.

[4] Wicaksono, Arie (2018), Strategi Pemasaran dengan Menggunakan Analisis Swot Tanpa Skala Industri pada PT. X di Jakarta. Jurnal Manajemen Industri dan Logistik, Vol. 1, No. 2, ISSN : 2598-5795. 
[5] Afifuddin, 2010, Pengantar Administrasi Pembangunan. Penerbit : CV Alfabeta, Bandung.

[6] Kuncoro, Mudrajad, 2017. Ekonomi Pembangunan, Penerbit : UPP AMP YKPN, Yogyakarta.

[7] Tambunan, Tulus, 2012, Usaha Mikro Kecil dan Menengah di Indonesia: Isu-Isu Penting, Penerbit : LP3ES, Jakarta.

[8] Suci, Y. R. (2017). Perkembangan UMKM (Usaha Mikro Kecil Dan Menengah) Di Indonesia. Jurnal Ilmiah Cano Ekononomos, 6(1), 51-58

[9] Oktafia, R. 2017. Percepatan Pertumbuhan Usaha Mikro, Kecil Dan Menengah (UMKM) Melalui Perkuatan Lembaga Keuangan Mikro Syariah (LKMS) Di Jawa Timur. In Proceedings of 1st Annual Conference for Muslim Scholars, Kopertais IV Surabaya, 1(1). 85-92.

[10] Sarwono, Hartadi dan Rijianto, Erwin, 2015. Profil Bisnis Usaha Mikro, Kecil, dan Menengah. Penerbit : Kerjasama LPPI dengan Bank Indonesia, Jakarta.

[11] Maskun, Sumitro dan Surjadi 2004, Pembangunan Masyarakat Desa, Penerbit : Media Widya Mandala, Yogyakarta.

[12] Sedarmayanti, 2014, Manajemen Strategi, Cetakan kesatu, penerbit : PT. Refika Aditama, Bandung.

[13] Tjiptono, Fandy, 2015, Strategi Pemasaran, edisi keempat, Penerbit : ANDI, Yogyakarta.

[14] Kotler, Philip dan Armstrong, Gary. 2014. Prinsip-prinsip Manajemen. Edisi keempatbelas, Jilid Satu, Penerbit : Bumi Aksara, Jakarta

[15] Porter, Michael, E. 2014. Keunggulan Bersaing. Tim Penerjemah Binarupa Aksara. Penerbit : Binarupa Aksara : Jakarta.

[16] Fahmi, Irham, 2017, Manajemen Strategis: Teori dan Aplikasi, Cetakan Kesatu, Penerbit : Alfabeta, Bandung.

[17] Siagian, P. Sondang, 2019, Manajemen Stratejik, Cetakan ketigabelas, Penerbit : Bumi Aksara, Jakarta

[18] Solihin, Ismail, 2015, Manajemen Strategik, penerbit :Erlangga, Jakarta.

[19] Udaya Jusuf, dkk, 2013, Manajemen Stratejik, edisi pertama, cetakan pertama, Penerbit : Graha Ilmu, Yogyakarta

[20] Robbins, Stephen, P. dan Mary Coulter. 2010. Manajemen, Jilid 1 diterjemahkan oleh Bob Sabran, dan Wibi Hardani. Edisi10, Cetakan ketigabelas. Penerbit : Erlangga, Jakarta.

[21] David, J. Hunger \& Thomas L. Wheelen, 2015. Strategic Management and Business Policy, 9th Edition, Pearson Prentice Hall, Zenith.

[22] Rivai, Veithzal dan Sagala, EJ. 2015. Manajemen Sumber Daya Manusia untuk Perusahaan: Dari Teori ke Praktek. Edisi Kedua, Penerbit : PT Raja Grafindo Persada, Jakarta.

[23] Lubis, B. Y. Hermanto dan E. Edison, 2018, Manajemen dan Riset Sumber Daya Manusia, penerbit : Alfabeta, Bandung.

[24] Mardikanto,Totok, 2014, Pemberdayaan Masyarakat Dalam Perspektif Kebijakan Publik. Penerbit: Alfabeta, Bandung.

[25] Zubaedi, 2013, Pengembangan Masyarakat Wacana dan Praktik, Penerbit : Kencana, Jakarta. 
[26] Rangkuti, Freddy, 2015, Analisis SWOT Teknik Membedah Kasus Bisnis,: Penerbit : Gramedia Pustaka Utama.

[27] Sedarmayanti, 2014, Manajemen Strategi, Cetakan kesatu, penerbit : PT. Refika Aditama, Bandung. 